\title{
Evaluation of Routine Coagulation Testing Requirements in Patients with Severe Epistaxis
}

\section{Ciddi Epistaksis olan Hastalarda Rutin Koagülasyon Teslerinin Değerlendirmesi}

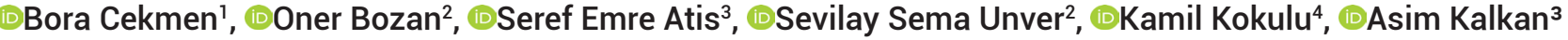 \\ ${ }^{1}$ Karabuk University, Faculty of Medicine, Department of Emergency Medicine, Karabük, Turkey \\ ${ }^{2}$ Cemil Tascioglu Hospital, Department of Emergency Medicine, İstanbul, Turkey \\ ${ }^{3}$ Mersin City Hospital, Department of Emergency Medicine, Mersin, Turkey \\ ${ }^{4}$ Aksaray University Faculty of Medicine, Department of Emergency Medicine, Aksaray, Turkey
}

Copyright@Author(s) - Available online at www.dergipark.org.tr/tr/pub/medr

Content of this journal is licensed under a Creative Commons Attribution-NonCommercial 4.0 International License.

\begin{abstract}
Aim: There are studies about coagulation parameters are not required in the management of epistaxis. The aim of the present study was to investigate whether or not coagulation tests are required and its relationship with medications in severe epistaxis cases that require intervention.

Material and Method: The patients above 16 years who had presented to emergency department due to epistaxis, who had undergone anterior/posterior nasal packing or electro-cautery to the nasal mucosa were included the study. The demographic characteristics, blood count, coagulation test, anti-platelet and anti-coagulant medications, the procedures carried out for stopping bleeding, whether reversal treatment or blood transfusion was needed were recorded.

Results: A total of 469 patients, it was found that coagulation parameters had been tested in $141(30.2 \%)$. While PT, aPTT and INR values of the anti-coagulant using patients were significantly higher $(p<0.001, p=0.003, p<0.001$, respectively), the platelet and hemoglobin values were not found to be associated with anti-platelet drug and anti-coagulant use $(p=0.304, p=0.098$, respectively). The patients were allocated to two groups as those any parameter of whom was impaired or not. While a significant difference was found between the groups with regard to hemoglobin values $(p=0.006)$, no patients were determined to need reversal treatment or hemoglobin replacement.

Conclusion: Routine coagulation testing is not required for patients who have epistaxis that cannot be stopped with conservative methods and who are using anti-platelet drugs as it does not lead to a difference in treatment. Coagulation tests may not be performed in patients who use anti-coagulants based on the results.
\end{abstract}

Keywords: Epistaxis, nose-bleed, coagulation, antiplatelet

Öz

Amaç: Epistaksis yönetiminde koagülasyon testlerinin gerekli olmadığını gösteren çalışmalar mevcuttur. Bu çalışmanın amacı, müdahale gerektiren ciddi burun kanamalarında pıhtılaşma testlerinin gerekli olup olmadığını ve ilaçlarla ilişkisini araştırmaktır..

Materyal ve Metot: Çalışmaya Acil Servis'e burun kanaması ile başvurmuş 16 yaş üstü, anterior veya posterior burun tamponu konulan veya nazal mukozaya koterizasyon uygulnan hastalar dahil edildi. Hastalara ait demografık veriler, tam kan sayımı, koagülasyon testleri, kullandığı antikoagülan ve anti-trombosit ilaçlar, kanamayı durdurmak için kullanılan yöntem ve kan transfüzyonu veya koagülasyon bozukluğu için kan ürünü alıp almadığı kaydedildi.

Bulgular. Toplam 469 hastadan 141 (\%30,2)'inin koagülasyon testlerinin çalışıldığı bulundu. Antikoagülan kullanan hastaların PT, aPTT ve INR değerleri anlamlı olarak yüksek bulunurken (sırasıyla $p<0,001, p=0,003, p<0,001$ ) trombosit ve hemoglobin değerlerinin antitrombosit ve antikoagülan kullanımı ile ilişkili olmadığı bulundu (sırasıyla $p=0.304, p=0.098$ ). Hastalar herhangi bir koagülasyon veya kanama parametresinde bozulma olan ve olmayan olarak iki gruba ayrıldı. Hemoglobin değerleri açısından gruplar arasında anlamlı fark bulunurken $(p=0,006)$, kan transfüzyonu veya koagülasyon bozukluğu için kan ürünü replasmanına ihtiyaç duyan hasta saptanmadı. Sonuç: Konservatif yöntemlerle durdurulamayan epistaksisi olan ve antitrombosit ilaç kullanan hastalarda tedavide fark yaratmadığı için rutin pıhtılaşma testi yapılmasına gerek yoktur. Antikoagülan kullanan hastalarda sonuçlara göre pıhtılaşma testleri yapılmayabilir.

Anahtar Kelimeler : Epistaksis, burun kanaması, koagülasyon, antiplatelet 


\section{INTRODUCTION}

Epistaxis is among the most common causes of bleeding of head and neck origin in patients presenting to the emergency room. This condition is usually not complicated and rarely difficult to control. Most cases can be controlled with nasal compression and topical vasoconstrictors (1). Although severe epistaxis cases that cannot be stopped with conservative methods may be controlled with anterior or posterior nasal packing, balloon catheter or electrical and medical cautery; surgical interventions (endoscopic ligation, embolization) may rarely be required (2). Coagulation parameters including platelet count, prothrombin time (PT), activated partial thromboplastin time (aPTT) and the international normalized ratio (INR) are still being tested in many centers besides the anamnesis and physical examination. However, some studies are available reporting that these tests are not necessary in the management of epistaxis, and it was concluded that these approaches increased the costs and the duration of hospital stay (3).

Many current studies include the whole epistaxis cases that can be controlled even with conservative treatments. The present study was conducted with the aim of investigating the necessity of coagulation tests and its relationship with the medications used.

\section{MATERIAL AND METHOD}

The present study was conducted at the Emergency Department of Okmeydani Research and Training Hospital, which is a tertiary center that accepts about 550,000 emergency room admissions annually. The data were retrospectively obtained from the electronic medical report system of the hospital. The patients above 16 years who had been admitted to emergency room due to epistaxis, who had undergone anterior/ posterior nasal packing or electro-cautery to the nasal mucosa between June 2017 and May 2019 were retrospectively included in the study. The demographic characteristics of the patients, blood count parameters, coagulation test results, anti-platelet (acetyl salicylic acid, [ASA], clopidogrel, prasugrel, ticagrelor) and anti-coagulant medications (warfarin, rivaroxaban, dabigatran, apixaban, edoxaban) used by the patients, the procedures carried out for stopping the bleeding, whether or not reversal treatment or blood transfusion were needed were recorded. The patients whose bleeding could be controlled spontaneously or with conservative treatment (nasal compression, topical vasoconstrictor), who were below 16 years of age, pregnant, who had trauma-related hemorrhage and whose medications could not be determined via the pharmacy system of the ministry of health, were excluded from the study.

The coagulation parameters were accepted as impaired if the values were as follows: $\mathrm{PT}>14.2 \mathrm{sec}, \mathrm{aPTT}>33 \mathrm{sec}$, INR $>1.2$, platelet count $<150,000$. It was investigated whether or not there was an association between these values and drug use, and the association between the medication and coagulation parameters in patients in whom any parameter was impaired.

The study was performed in accordance with the Declaration of Helsinki and was approved by the Ethics Committee of Okmeydani Training and Research Hospital, Istanbul, Turkey (Approval No. 1087).

\section{Statistical Analysis}

Statistical analyses were performed using the SPSS for Windows version 15.0 (SPSS Inc., Chicago, IL, USA). In the comparison of the continuous variables between the two groups, the Mann Whitney $U$ test was used for the variables that were not normally distributed, and the independent sample $t$ test was used for the normally distributed continuous data. The Chi-square test or the Fisher's exact test was used for comparison of the categorical variables. For comparison of the continuous variables among three groups, the one-way variance analysis (ANOVA) was used for the normally distributed continuous variables and the Kruskal-Wallis test was used for the non-normally distributed continuous variables. The Post-hoc Tukey test, the Welch ANV or the Bonferroni correction was used for the subgroup comparisons.

\section{RESULT}

A total of 469 patients who had been admitted to the emergency room due to epistaxis and undergone one of anterior/posterior nasal packing or nasal mucosa cautery, were included in the study. Of these patients, $141(30.2 \%)$ were determined to have been tested for coagulation parameters and enrolled in the study. 78 (\%55.3) of the patient in the study were male. The mean age of the patients was $61,9( \pm 19.0)$. The demographic and clinical characteristics of the patients have been presented in Table 1.

While $94(66.7 \%)$ patients were not using any medications, $28(20 \%)$ were using ASA and other anti-platelet combinations; $16(11 \%)$ of them were using only ASA and $3(2 \%)$ were using clopidogrel. Of the patients who were using anti-coagulants, $8(5.6 \%)$ were using rivaroxaban and $6(4.2 \%)$ were using warfarin. While the PT, aPTT and the INR values of the patients who were using anticoagulants were significantly high $(p>0.001, p=0.003$ and $p>0.001$, respectively), the platelet and the hemoglobin values were not found to be related to anti-platelet and anti-coagulant use ( $p=0.304$ and $p=0.098$, respectively).

Patients whose platelet count was low, INR value was high and the PT and aPTT were elevated, constituted a group, and the patients were allocated to two groups as those, any parameter of whom was impaired or not. While a significant difference was determined between these two groups with regard to the hemoglobin values $(p=0.006)$, none of the patients whose coagulation parameter was impaired required reversal treatment and hemoglobin replacement (Table 2). 
Table 1. Demographic and Clinical Characteristics of Patients

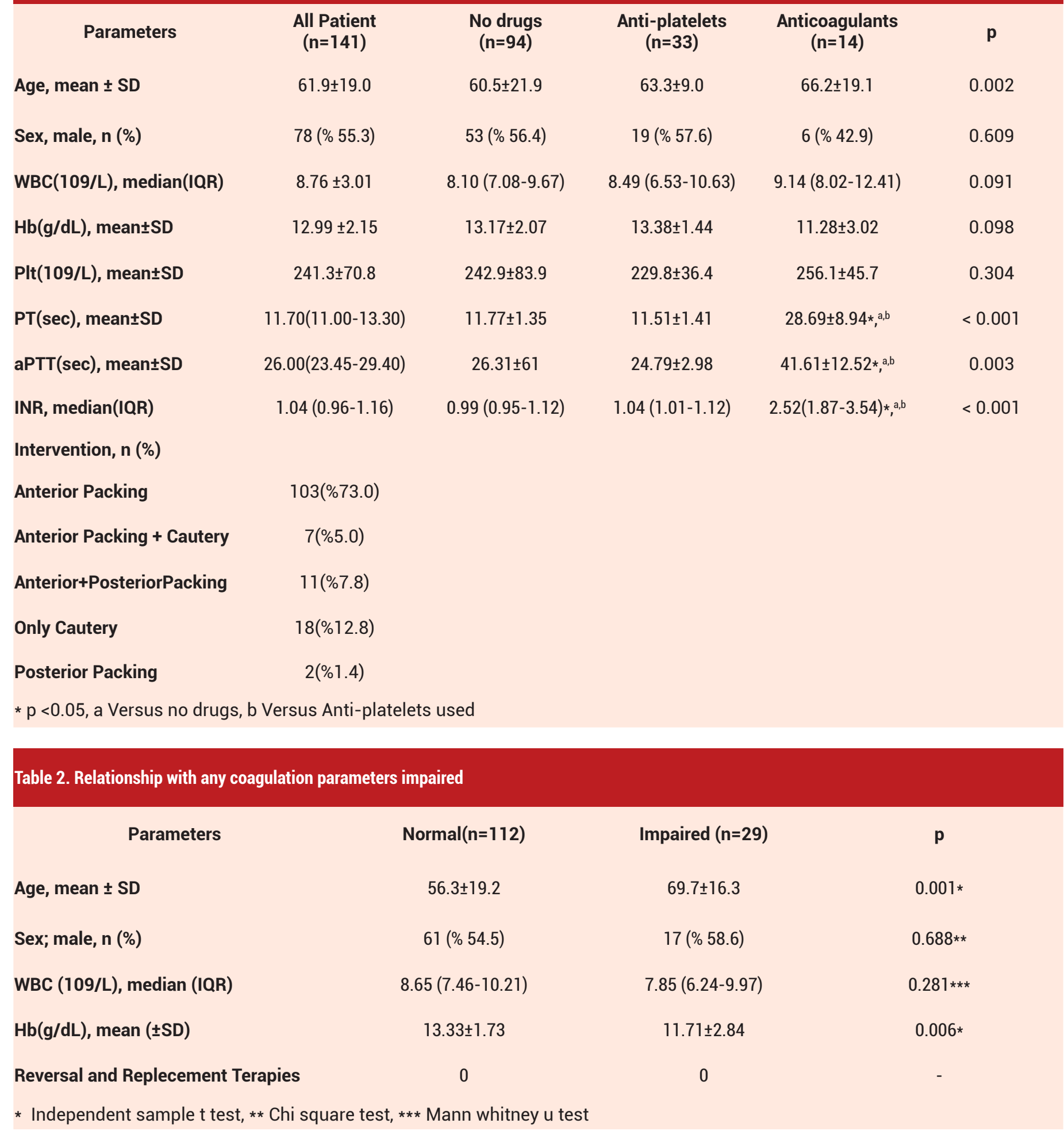

\section{DISCUSSION}

The present study including 141 patients investigated the patients whose coagulation test could be impaired without the absence of anti-coagulant and anti-platelet use or history of any medication. While the elevations in the INR values are related to anti-coagulant drugs, an association between this condition and the treatment given to the patient could not be demonstrated. Besides, a significant alteration was not observed in the tests of the patients who were receiving anti-platelet agents.

Many studies state that INR should be controlled in patients who are using warfarin and whose epistaxis does not respond to local measures $(4,5)$. Similarly, discontinuation of anti-platelet drugs is not meaningful as their effect lasts up to 10 days besides knowing that discontinuation of anti-coagulants is not useful in acute hemorrhages. 
Consulting with a hematologist or cardiologist may be needed for arrangement of treatment only when the hemorrhage is massive and cannot be stopped or in case of anti-coagulant over-dose (6). On the other hand, the rate of the need for reversing anti-coagulation was reported as only $0.15 \%$ yearly in epistaxis developing in patients using anti-coagulants in a large retrospective study (7). In our study, no patients required reversal and replacement therapy. Hence, it was concluded that coagulation testing could not be useful unless the presence of a bleeding that could not be controlled despite treatment even if the patients were using warfarin.

In the present study, the hemoglobin levels of the patients whose coagulation parameters were impaired were found to be significantly low. No patients required blood transfusion. In a large cohort of 591 patients, the need for blood replacement was investigated in patients with epistaxis and showed that only 2 out of 22 patients receiving replacement were using anti-coagulant and anti-platelet agents (8). A strong association was demonstrated between epistaxis surgery and blood transfusions, particularly posterior hemorrhages requiring surgical intervention (9). In our patient population, posterior tampon was applied to only $2(1.4 \%)$ patients; this low rate may be the reason for not requiring replacement treatment.

\section{Limitations}

Our study has many limitations due to its retrospective design. Re-admissions of these patients could have been to other centers and this could not be evaluated due to limited access to data. The seniority of the clinicians who ordered the tests was not considered and we suggest that this could lead to a difference. However, the study was designed retrospectively as a prospective design could lead to bias. Although our patient population is relatively small, the population can be widened so as to include the patients who required surgical intervention and/or transfusion.

\section{CONCLUSION}

Routine testing of coagulation parameters is not necessary as it would not change the treatment in patients who are using anti-platelet agents and whose epistaxis cannot be controlled with conservative treatments. Based on our data, routine testing is not required in patients using anti-coagulants; however, studies are required conducted with larger populations including patients who use anticoagulants (particularly warfarin) for making this suggestion.

Financial disclosures: All authors declare no financial support.

Conflict of Interest: The authors declare that they have no competing interest.

Ethical approval: The study was performed in accordance with the Declaration of Helsinki and was approved by the Ethics Committee of Okmeydani Training and Research Hospital, Istanbul, Turkey (Approval No. 1087).

\section{REFERENCES}

1. Purkey MR, Seeskin Z, Chandra R. Seasonal variation and predictors of epistaxis. Laryngoscope 2014;124:2028-33.

2. Riviello RJ. Otolaryngologic procedures. In: Clinical Procedures in Emergency Medicine, 4th, Roberts JR, Hedges JR (Eds), WB Saunders, Philadelphia, 2004; p.1300.

3. Awan MS, Iqbal M, Imam SZ. Epistaxis: when are coagulation studies justified? Emerg Med J. 2008;25:156-7.

4. Horton JD, Bushwick B Warfarin therapy: evolving strategies in anticoagulation. Am Fam Physician 1999;59:635-46.

5. Béquignon E, Teissier N, Gauthier A, et al. Emergency department care of childhood epistaxis. Emerg Med J. 2017;34:543-8.

6. Beck R, Sorge M, Schneider A, Dietz A: Current approaches to epistaxis treatment in primary and secondary care. Dtsch Arztebl Int. 2018;115:12-22.

7. Nitu IC, Perry DJ, Lee CA. Clinical experience with the use of clotting factor concentrates in oral anticoagulation reversal. Clin Lab Haematol. 1998;20:363.

8. Murer K, Ahmad N, Roth BA, Holzmann D, Soyka MB. THREAT helps to identify epistaxis patients requiring blood transfusions. Journal of Otolaryngology. Head Neck Surg. 2013;42:4.

9. Barlow DW, Deleyiannis WB, Pinczower EF. Effectiveness of surgical management of epistaxis at a tertiary care center. Laryngoscope. 1997;107:21-4. 